\title{
PENGEMBANGAN BUKU PANDUAN PELAKSANAAN KONSELING KELOMPOK DENGAN TEKNIK ASSERTIVE TRAINING UNTUK MENINGKATKAN PERILAKU ASERTIVITAS SISWA KORBAN PERUNDUNGAN SIBER
}

\author{
Ferisa Maharani ${ }^{1}$, Rahmawati $^{2}$, Arga Satrio Prabowo ${ }^{3}$ \\ Universitas Sultan Ageng Tirtayasa \\ ferisamhrn32@gmail.com
}

\begin{abstract}
Abstrak
This research was conducted using $R \& D$ (Research and Development) approach or development research that produces a product. This study aims to know the quality and describe the procedure of developing implementation manuals, to address the behavior of students victims of cyber abuse. The resulting development product is an implementation manual. In the initial development process, the developer consults with media experts, material experts, as well as practitioners (guidance and counseling teachers) to get input and advice on the products developed. This research instrument is a questionnaire of asertive behavior. The results of the assessment are analyzed using descriptive percentage analysis techniques. The results of the research obtained from the validation of expert tests and practitioner tests (guidance and counseling teachers) showed that the implementation manual is classified as a good category and scored 4.1. Thus the product is declared worthy to be used as a medium in information services to improve the behavior of students victims of cyber abuse.
\end{abstract}

Kata Kunci : research and development, guidebooks, assertive training, victims of cyber bullying

\section{PENDAHULUAN}

Pesatnya perkembangan teknologi informasi dan komunikasi telah mengubah cara manusia berinteraksi dengan manusia lainnya. Berbagai media sosial digunakan sebagai sarana interaksi sosial, yang mendukung hal tersebut. Laporan Tinjauan Global Digital (Simon Kemp, 2019) jumlah pengguna internet diseluruh dunia memiliki peningkatan menjadi 4,54 miliar, meningkat 7\% dibandingkan Januari 2019 (298 juta pengguna baru). Hingga Januari 2020, terdapat 3,8 miliyar pengguna media sosial di segala tempat, dan jumlah ini meningkat lebih dari 9\% (321 juta pengguna baru). Di Indonesia, antara 2019 dan 2020, pengguna internet meningkat sebanyak 25 juta orang (17\%). Tingkat penetrasi internet di Indonesia mencapai $64 \%$ pada Januari 2020. Hingga Januari 2020, Indonesia memiliki 160 juta pengguna media sosial, dan jumlah telepon seluler di Indonesia setara dengan $124 \%$ dari total penduduk. Terkait peningkatan penggunaan internet, hasil survei Latitude News menunjukkan bahwa 
bentuk kekerasan yang sering dialami anak muda saat ini adalah perundungan siber. Indonesia memiliki salah satu tingkat perundungan tertinggi kedua di dunia, terutama melalui jejaring sosial (Satalina, 2014). Hasil penelitian Afriyeni dan Sartana (2017) menunjukkan bahwa korban perundungan siber pada remaja perempuan lebih banyak dibandingkan remaja laki-laki. Jumlah mereka 99 (58\%), sedangkan korban laki-laki hanya 73 (44\%). Penelitian lain juga membuktikan hal ini, bahwa wanita lebih mungkin menerima perundungan siber dari pada laki-laki dengan bullying tradisional (Fautcher, Jackson and Cassidy, 2014). Perundungan siber memiliki berbagai bentuk, termasuk penghinaan, unggahan foto, bahkan mengunjungi akun media sosial orang lain melalui email dan website untuk menyebarkan informasi palsu sehingga membuat korban merasa dipaksa (Rifauddin, 2016). Salah satu faktor yang terkait dengan konsep bunuh diri adalah bullying. penelitian yang menunjukkan pengalaman teman yang memalukan (terutama sebagai target tetapi juga sebagai pelaku) dapat menyebabkan depresi, penurunan harga diri, putus asa dan kesepian, yang semuanya dapat memicu pikiran dan perilaku bunuh diri. Dari kejadian tersebut perlu dicegah agar tidak semakin parah di sekolah. Perundungan siber memiliki banyak dampak, salah satunya adalah sikap asertivitas korban perundungan siber (Fautcher, Jackson, 2014). Dampak yang ditimbulkan sangat memberikan pengaruh besar pada remaja khususnya. Perlu ada upaya yang harus dilakukan dalam mengatasi fenomena tersebut, agar siswa sebagai remaja yang berkembang dapat beradaptasi, berinteraksi, menggunakan internet dengan baik sesuai dengan tujuannya. Kemudian Soendjojo (dalam Gowi dan Jennifer, 2009) menjelaskan bahwa karakteristik utama korban perundungan adalah siswa yang belum mampu bersikap asertif. Karenanya perlu penelitian pengembangan buku panduan pelaksanaan layanan terlebih dahulu untuk menerapkan teknik assertive training pada korban perundungan siber.

Perundungan siber yakni perilaku berbahaya yang disengaja terjadi berulang kali melalui penggunaan komputer, ponsel, atau perangkat elektronik lainnya (Hinduja dan Patchin, 2008). perundungan siber sebagai tindakan yang dirancang untuk menargetkan seseorang melalui peniruan, sumpah, dan ancaman melalui pesan teks, email, gambar, atau pesan video (Williams dan Guerra, 2013). Secara umum siswa yang terkena dampak negatif perundungan adalah siswa yang memiliki tingkat asertivitas rendah. Orang dengan sikap asertif yang rendah memiliki banyak ketakutan yang tidak rasional, termasuk mereka yang menunjukkan kecemasan dan gagal mempertahankan hak pribadinya. Demikian pula, Korban perundungan mereka tidak mampu menunjukkan perlawanan terhadap perundungan karena siswa yang menjadi korban perundungan takut bahwa pelaku perundungan akan memperburuk perundungan”. Orang yang asertif dapat mengekspresikan emosi dengan tegas, mencapai tujuan tertentu, dan mencapai kedamaian juga kebahagiaan dalam hidup. Juga menekankan kalau orang yang asertif dapat mengekspresikan emosinya tanpa rasa khawatir, dan dapat mencapai tujuan hidup. Perilaku asertif seseorang akan dipengaruhi oleh lingkungan sekitar individu tersebut.

Penggunaan layanan konseling kelompok dapat membantu siswa yang mengalami kesulitan dalam mengungkapkan emosinya melalui diskusi diharapkan siswa dapat berlatih mengungkapkan pendapat dengan pengetahuan dan gagasannya, mempertahankan pendapatnya, dan menyatakan persetujuan atau penolakan pendapat orang lain. Ada beberapa pendekatan konseling kelompok, salah satunya adalah pendekatan behavior. Pendekatan behavior adalah pendekatan untuk mengubah perilaku. Dalam pendekatan behavior ada sebagian metode yang salah satunya ialah teknik assertive training. Tujuannya yaitu supaya siswa mempunyai sikap percaya diri. sikap asertif dibagi dalam 5 aspek, yakni percaya diri, tanggung jawab, kepastian, kejujuran, serta menghormati terhadap orang lain. Salah satu layanan bimbingan dan 
konseling untuk menangani korban perundungan dan perundungan siber siswa melalui assertive training (Aziz, 2015). Menurut Arumsari (2017) Strategi konseling assertive training untuk konseli yang mengalami perundungan adalah salah satu bantuan yang bisa diberikan oleh konselor. Hal ini dilakukan agar setiap orang dapat mengekspresikan kemampuan interpersonalnya tanpa merugikan orang lain. Strategi konseling assertive training mengacu pada intervensi yang melatih individu untuk mengekspresikan pikiran dan perasaan mereka tanpa membahayakan orang lain. Kemudian Aziz (2015) menjelaskan dapat disimpulkan bahwa setelah mengikuti assertive training, siswa yang mengalami perundungan dapat menunjukkan sikap asertif saat menghadapi masalah. Siswa memperoleh keterampilan untuk mengekspresikan emosi negatif, penegasan diri dan mengekspresikan emosi positif. Assertive training diharapkan bisa menjadi sarana untuk mencapai tujuan memahami nilai-nilai positif bagi siswa, terutama dalam meningkatkan perilaku asertivitas siswa korban perundungan siber.

\section{METODE}

Jenis penelitian yang digunakan dalam penelitian ini yaitu penelitian pengembangan dimana menghasilkan produk dalam bentuk media pembelajaran. Metode R\&D adalah metode yang menghasilkan produk tertentu serta dapat teruji keefektifan produknya. Penelitian ini bertujuan untuk mengembangkan media pembelajaran berupa buku panduan pelaksanaan konseling kelompok dengan teknik assertive training untuk meningkatkan perilaku asertivitas korban perundungan siber. Prosedur penelitian menggunakan model pengembangan ADDIE yang meliputi lima tahapan yaitu analysis, desain, development, implementation and evaluation. Bertujuan dapat memudahkan guru BK dalam melaksanakan pelayanan BK dan diharapkan dapat menjadi acuan bagi guru BK dalam melakukan pelaksanaan layanan konseling yang diberikan. Lokasi yang digunakan dalam penelitian ini berada di wilayah Tangerang dengan sasaran yang dituju adalah siswa dan digunakan bagi guru BK. Subjek penelitian ini adalah 23 siswa SMA. Teknik pengambilan data menggunakan instrumen pengungkap perilaku asertivitas berupa angket sebanyak 41 butir pernyataan, serta pengambilan sampel melalui random sampling mengenai perilaku asertivitas siswa korban perundungan siber. Berdasarkan hasil uji alat ukur didapatkan persentase $70 \%$ sebanyak 16 siswa berada pada tingkat perilaku asertivitas yang rendah.

\section{HASIL DAN PEMBAHASAN}

Pengembangan media pembelajaran buku panduan yang digunakan dengan guru BK bagi siswa divalidasi oleh para ahli yang dilakukan di kampus Universitas Sultan Ageng Tirtayasa (Untirta), Fakultas Keguruan dan Ilmu Pendidikan (FKIP), sedangkan validasi praktisi buku panduan dilakukan kepada beberapa guru BK yang berada di wilayah Tangerang dan sekitarnya. Para ahli terkait termasuk ahli materi juga ahli media. Ahli materi yang ditunjuk yakni dosen yang mumpuni di bidangnya Bimbingan dan Konseling dan sudah mendapatkan gelar sebagai doktor, pada penelitian dan pengembangan ini dipilih Ibu Dr. Hj. Evi Afiati, M.Pd. Ahli media yang ditunjuk adalah dosen yang mumpuni di bidangnya Bimbingan dan Konseling juga media pembelajaran, pada penelitian dan pengembangan ini dipilih Bapak Alfiandhy Warih Handoyo, M.Pd. Kedua ahli yang ditunjuk tersebut merupakan dosen Jurusan Bimbingan dan Konseling FKIP Untirta. Uji coba praktisi media pembelajaran dilakukan kepada beberapa guru BK di wilayah Tangerang dan sekitarnya. Uji coba praktisi dilakukan melalui google formulir yang berupa angket juga komentar dan saran, serta dikomunikasikan melalui via personal chat kepada guru BK yang ditunjuk sebagai praktisi. 
Produk yang telah dikembangkan peneliti divalidasi dengan dosen ahli materi sebelum dilakukan percobaan oleh praktisi. Tujuan validasi ini adalah untuk mendapatkan data kelayakan media pembelajaran dilihat pada aspek materi dan mendapatkan komentar juga saran tentang kebenaran isi materi. Juga dapat menjadi produk yang berkualitas baik dari segi keterampilan berekspresi, pengelolaan pembelajaran, pemilihan gambar dan konten pada media pembelajaran.

Produk yang dikembangkan pada penelitian berupa pengembangan program konseling kelompok untuk meningkatkan perilaku asertif siswa korban perundungan siber yang dikemas dalam bentuk buku panduan pelaksanaan. Proses pengembangan produk mengacu pada struktur pengembangan program yang tertera pada panduan operasional pelaksanaan bimbingan dan konseling (POP BK). Sementara untuk desain penelitian yang digunakan yaitu model pengembangan ADDIE: analysis, design, development, implementation, and evaluation (Sugiyono, 2012). Adapun prosedur ADDIE yang digunakan pada penelitian dan pengembangan ini hanyalah tiga tahapan, yaitu sampai tahap development dengan dilakukan uji ahli dan praktisi, adapun tahap implementation dan evaluation dijadikan sebagai rancangan untuk penelitian selanjutnya. Penelitian mengacu kepada panduan operasional pelaksananaan konseling kelompok, yaitu dirumuskan berdasarkan rasional dan deskripsi kebutuhan. Berikut ini rasional dan deskripsi kebutuhan yang telah dirancang oleh peneliti dari hasil analisis lapangan:

a) Rasional. Penyusunan rasionalisasi program pengembangan disusun berdasarkan hasil analisis pada tujuan pendidikan nasional dan urgensi perilaku asertivitas siswa korban perundungan siber dalam proses pembelajaran.

b) Deskripsi kebutuhan. Disusun berdasarkan pada fenomena permasalahan siswa yang terjadi di lapangan melalui penyebaran angket perilaku asertif siswa yang diadaptasi dari tugas akhir yang dikembangkan oleh Dewi Fatimah (2013). Berikut ini deskripsi kebutuhan yang diperoleh dari hasil analisis lapangan: Hasil studi pendahuluan yang dilakukan pada 23 siswa SMA mengenai perilaku asertivitas siswa korban perundungan siber, diperoleh data sebanyak 16 siswa atau jika dipersentasekan sebesar $70 \%$ siswa yang memiliki tingkat perilaku asertivitas rendah.

Berdasarkan data hasil angket studi pendahuluan dapat terlihat bahwa siswa yang dikategorikan memiliki tingkat perilaku asertivitas rendah cukup banyak. Data lain dari hasil survei Studi Sartana dan Afriyeni (2017) menunjukkan bahwa korban perundungan siber pada remaja perempuan lebih banyak dibandingkan remaja lakilaki. Jumlah mereka 99 responden (58\%), sedangkan korban laki-laki hanya 73 (44\%). Penelitian dari GSMA Intelligence, di Indonesia pengguna internet meningkat dengan 25 juta orang (17\%) selang 2019 juga 2020. Tingkat penembusan internet di Indonesia mencapai $64 \%$ di Januari 2020, dan Indonesia memiliki 160 juta pengguna media sosial pada Januari 2020. Total koneksi seluler di Indonesia Januari 2020 sama dengan 124\% dari jumlah populasi jiwa yang ada. Sehubungan dengan meningkatnya penggunaan internet, hasil survei Latitude News menunjukkan bahwa bentuk kekerasan yang sering dialami anak muda saat ini adalah perundungan siber. Indonesia merupakan salah satu negara dengan tingkat perundungan tertinggi kedua di dunia, terutama melalui jejaring sosial. Gambaran perilaku cyberbullying di sekolah dapat dilihat dari kebiasaan dan aktivitas siswa dalam menggunakan media internet. Penelitian Wang, Kowalski dan Limber (Yilmaz, 2011:647) yang menginvestigasi siswa pada kelas 6-10 dan teridentifikasi 5,3\%-11\% pernah menjadi korban cyberbullying, 4,5\%-7\% menjadi korban bully, dan 3,8\%-4\% mem-bully. Hasil survei Ilham (2018) Mengatakan gambaran perilaku cyberbullying di sekolah dapat dilihat dari kebiasaan dan aktivitas 
siswa dalam menggunakan media internet. yang sering di posting terkait perasaan dan kritikan terhadap seseorang dan oknum serta hampir semua siswa pernah melakukan bullying atau terdapat 32\% dimana mereka melakukan bullying seperti mengejek, menjewer, memalak dan mempostingnya diinternet. Berdasarkan data dan fakta yang diperoleh maka permasalahan yang menjadi penyebab karakteristik utama korban perundungan siber yaitu banyaknya dampak yang ditimbulkan pada korban perundungan siber. Sementara dari hasil studi pendahuluan diperoleh inti permasalahan yang dialami siswa mengenai permasalahan perundungan siber yaitu siswa yang menjadi korban perundungan siber belum mampu bersikap asertif. Berdasarkan hasil analisis permasalahan yang terjadi dilapangan, maka peneliti melakukan perencanaan pengembangan program konseling kelompok dengan teknik assertive training untuk meningkatkan perilaku asertivitas siswa korban perundungan siber.

Penelitian pengembangan ini yakni penelitian tentang memproduksi produk berbentuk media pembelajaran yang disediakan pada format buku pedoman pelaksanaan. Penelitian berawal dari rencana pengembangan hingga menguji praktisi media pembelajaran, kemudian dapat disebar luaskan. Uji coba praktisi dilaksanakan sekali oleh peneliti yang dilakukan secara online menggunakan pengisian instrumen dalam bentuk google formulir. Berdasarkan hasil penelitian diatas terlihat bahwa media pembelajaran buku panduan pelaksanaan yang dikembangkan peneliti telah menunjukkan bahwa media pembelajaran tersebut layak untuk digunakan.

Bersumber pada hasil validasi oleh ahli media diperoleh bahwa penyajian, kegunaan dan interaktivitas media pembelajaran yang dikembangkan peneliti telah divalidasi oleh ahli media. Skor rata-rata dari hasil validasi oleh ahli media adalah 4,0. Skor tersebut sebenarnya menunjukkan perkembangan media pembelajaran yang diuji dari segi penyajian, kebermanfaatan, dan interaktif. Berdasarkan kriteria kelayakan rata-rata skor akhir diperoleh adalah $\overline{X \imath}+0,6 \times \mathrm{SBi}<\mathrm{X}<\overline{X \imath}+1,8 \times \mathrm{SBi}$ dengan ratarata $>3,4-4,2$ atau pada kategori "Baik". Dapat disimpulkan bahwa media pembelajaran yang dikembangkan peneliti memiliki kelayakan yang baik juga dapat digunakan sebagai media pembelajaran. Untuk validasi praktisi peneliti memperoleh data dari beberapa guru BK (praktisi media pembelajaran), dengan skor rata-rata 4,3. Nilai rata-rata berada pada $\mathrm{X}>\bar{X} \iota+1,8 \times \mathrm{SBi}$, dan range $>4,2$, atau dalam kategori "sangat baik". Berdasarkan hasil validasi guru BK, dapat disimpulkan bahwa media pembelajaran yang dikembangkan peneliti sesuai untuk digunakan dilihat dari media dan materi yang terdapat pada media pembelajaran tersebut. Berdasarkan uraian di atas dapat dijelaskan bahwa skor rata-rata hasil validasi ahli materi adalah 3,9 ; ahli media 4,0; dan praktisi 4,3. Rata-rata dari ketiga hasil validasi tersebut sebesar 4,1 yang tergolong kategori "Baik". Secara keseluruhan, hasil validasi menunjukkan bahwa media pembelajaran buku panduan pelaksanaan konseling kelompok dengan teknik assertive training untuk meningkatkan perilaku asertivitas siswa korban perundungan siber oleh peneliti dinyatakan layak untuk digunakan.

\section{KESIMPULAN}

Berdasarkan hasil penelitian dan pengembangan dapat diambil kesimpulan bahwa penelitian dan pengembangan yang dilakukan peneliti telah mencetuskan produk yang dikembangkan berbentuk buku panduan pelaksanaan konseling kelompok dengan teknik assertive training untuk meningkatkan perilaku asertivitas siswa korban perundungan siber, yang dikembangkan menggunakan model ADDIE. Proses pengembangan ADDIE terdiri dari lima langkah, yaitu 1) Analysis (analisis) menganalisis masalah melalui kegiatan observasi serta analisis kebutuhan dengan 
memberikan instrumen perilaku asertif kepada siswa; 2) Design (perancangan) melalui konten dan deskripsi buku yang akan digunakan; 3) Development (pengembangan) melalui pencarian sumber buku, pengumpulan bahan, pengembangan layanan, dan evaluasi; 4) Implementation (implementasi) melalui menguji cobakan buku panduan pelaksanaan terhadap siswa dan digunakan bagi guru BK, dan 5) Evaluation (evaluasi) melalui mengevaluasi hasil validasi dan pengujian produk pada siswa dan digunakan bagi guru BK dalam evaluasi sumatif, serta mengevaluasi hasil pre-test dan post-test selama layanan konseling yang diberikan kepada siswa berlangsung sebagai evaluasi formatif. Namun produk ini hanya selesai sebelum pada tahap implementasi, yaitu produk yang telah dikembangkan dilakukan uji coba atau diimplementasikan ke lapangan dikarenakan adanya wabah COVID-19, sehingga sekolah ditutup sampai batas waktu yang tidak ditentukan. Meskipun hanya sampai pada tahap ketiga, produk ini sudah melewati tahap validasi dan kelayakan oleh ahli juga uji praktisi dengan guru BK sehingga layak untuk digunakan. Buku panduan pelaksanaan menyandang kategori "baik" dengan skor rata-rata 4.1 maka hasil keseluruhan menunjukkan bahwa media pembelajaran buku panduan pelaksanaan oleh peneliti dinyatakan layak untuk digunakan.

\section{DAFTAR PUSTAKA}

Afriyeni. N., \& Sartana. (2017). Perundungan Maya (Cyberbullying) pada Remaja Awal. Jurnal Psikologi Insight. Vol 1 No 1. Hal 30-31. Diunduh pada https://ejournal.upi.edu/index.php/insight/article/download/8442/5299. Diakses Juli 2020.

Arumsari, C. (2017). Strategi konseling latihan asertif untuk mereduksi perilaku bullying. Journal Of Innovative Counseling: Theory, Practice, And Research. 1(01), 31-39. 05.09.2020.

Aziz, A. R. (2015). Efektivitas Pelatihan Asertivitas Untuk Meningkatkan Perilaku Asertif Siswa Korban Bullying. Jurnal Konseling dan Pendidikan Vol 3 No 2 Juni 2015 : 8-14. Diakses 13 Februari 2017 dari http://jurnal.konselingindonesia.com

Australian Federal Police (AFP). (2017). Jenis-jenis cyberbullying dan perkembangannya. Diakses pada website: http://costofgoodsold.blogspot.co.id/ 16.08.2020.

Depdiknas. (2007). Rambu-rambu penyelenggaraan pelayanan bimbingan dan

Faucher, C., Jackson, M. \& Cassidy, W. (2014). Cyberbullying among University Students: Gendered Experiences, Impacts, and Perspectives. Hindawi Publishing Corporation Education Research International.

Gowi, H., \& Jennifer, D. (2009). Penanganan Kekerasan di Sekolah. Jakarta: Indeks (Alih bahasa Ursula Gyani).

Hinduja, S., \& Patchin, J. W. (2008). Cyberbullying: An exploratory analysis of factors related to offending and victimization. Deviant Behavior, 29(2), 1- 29. http://dx.doi.org/10.1080/01639620701457816.

Kemp, Simon. (2019). Digital 2019: Indonesia. Datareportal. Retrieved from https://datareportal.com/reports/digital-2019-indonesia

Rifauddin, M. (2016). Fenomena cyberbullying pada remaja (Studi analisis media sosial facebook). Jurnal Khizanah Al-Hikmah. 4(1), 35-44. 03.07.2020. 
Sagita, F. (2014). Pengembangan media pembelajaran menggunakan program lectora dengan materi proses pembentukan muka bumi untuk siswa smp kelas VII. Skripsi Fakultas IImu Sosial Universitas Negeri Yogyakarta. 49-52. 16.06.2020.

Satalina, D. (2014). Kecenderungan Perilaku Cyberbullying Ditinjau Dari Tipe Kepribadian Ekstrovert dan Introvert. Jurnal Ilmiah Psikologi Terapan. 2(2), 294310.

Sugiyono.( 2012). Metode penelitian pendidikan. Bandung: Alfabeta. Update 10-2020.

Yilmaz, H. 2011. Cyberbullying in Turkish middle schools: An Exploratory Study. School Psychology International, 32(6), 645-654. 